Reprod. Nutr. Dévelop., 1984, 24 (2), 95-105.

\title{
Changes in steroid concentrations in follicular fluid and sexual behavior during pseudopregnancy in the rabbit
}

\author{
Monique CAILLOL, Aline SOLARI, J. LEFEBVRE (*) \\ Station de Physiologie animale, \\ (*) Station de Génétique factorielle, \\ INRA, 78350 Jouy-en-Josas, France.
}

Summary. Changes in sexual behavior and progesterone, oestrone, oestradiol, testosterone and androstenedione concentrations have been studied in the follicular fluid of 25 pseudopregnant rabbits on Days 6, 9, 12, 15 and 18. The sexual behavior score seemed to rise at the end of pseudopregnancy and follicular steroid levels were higher on Days 6 and 18 of pseudopregnancy than on Days 9, 12 or 15 . The generalized distance $D^{2}$ of Mahalanobis showed the existence of four periods during pseudopregnancy : Day 6, Days 9 and 12 which were similar, Day 15 and Day 18 . These stages were found to differ by a compound of the sexual behavior score and the concentrations of androgens and oestradiol in follicular fluid. There was no relationship between sexual behavior and follicular steroid concentrations. Nevertheless, undetectable levels of oestradiol. in the follicular fluid were only observed in deeply dioestrous females.

\section{Introduction.}

Despite high circulating progesterone levels during pseudopregnancy, doe rabbits may display oestrous behavior (Hammond and Marshall, 1925 ; Caillol et al., 1983). During this period, circulating oestrogen levels are too low and variable to be clearly related to sexual behavior (Caillol et al., 1983). The ovarian follicles are the only compartment aromatizing androgens and synthesizing oestrogens (Marchut, 1977), and the mean concentration of sex steroids is far higher in follicular fluid than in peripheral serum. Furthermore, in non-pregnant nonpseudopregnant rabbits, there is a relationship between sexual behavior and sex steroid concentrations in follicular fluid (Lefevre and Caillol, 1978). In this species, few data are available concerning the pattern of follicular sex steroids during pseudopregnancy. Osteen and Mills (1980) have shown that large, steroidogenically active follicles reappeared between Days 2 and 6 of pseudopregnancy ; they did not give any information on the second part of this period.

Therefore, in the present study we have tried to describe changes in sexual behavior by using a previously reported scoring system (Caillol et al., 1983) and in sex steroid concentrations in follicular fluid from Days 6 to 18 of pseudopregnancy. 


\section{Material and methods.}

Animals. - Twenty-five virgin female New Zealand rabbits housed in individual cages and fed commercial pellets ad libitum were used when 4 to 5 -months old. Pseudopregnancy was induced by an i.v. injection of $50 \mathrm{IU}$ of hCG (Day of injection = Day 0 of pseudopregnancy) in females displaying a red, turgescent vulva suggesting sexual receptivity (Lefèvre and Moret, 1978). The presence of recent ovulations was controlled $24 \mathrm{~h}$ later by laparotomy under fluanisone anesthesia.

Comportmental tests and sexual behavior score. - Pseudopregnant females were presented to 3 different males, the females being placed in the cage of the male for $60 \mathrm{sec}$. Comportmental tests were performed on Days 6, 9, 12, 15 and 18 of pseudopregnancy ( 5 animals per group). In each test, flattening in a corner of the cage, circling away from the male or mounting the male and lordosis was noted. As soon as a female displayed lordosis, she was promptly removed to prevent intromission and was not presented to the other males.

Female sexual behavior was scored according to Caillol et al. (1983) : flattening throughout the test was considered as a criterion of dioestrus, circling as a step towards submission to mating, and mounting and lordosis as a criterion of oestrus. A flattening female scored -1 , a flattening and circling female 0 , and a circling female +1 ; mounting scored +2 and lordosis +3 . The sexual behavior score was the mean of the notes obtained.

The females were killed immediately after the tests, their ovaries were recovered, and follicular fluid from all follicles larger than $0.5 \mathrm{~mm}$ in diameter was aspirated from one ovary with a 26-gauge needle and syringe. The fluid was weighed and stored at $-20^{\circ} \mathrm{C}$ until assay.

Steroid radioimmunoassay in follicular fluid. - The fluids of individual females were assayed separately. Progesterone $(P)$, oestrone $\left(E_{1}\right)$, oestradiol-17 $\beta\left(E_{2}\right)$, testosterone $(T)$ and androstenedione $\left(\Delta_{4}\right)$ were assayed.

Chemicals. - Non-radioactive steroids were purchased from Steraloids. Radioactive steroids were obtained from the Radiochemical Centre (Amersham). Merck analytical-grade solvents were used without re-distillation.

Assays. - The thawed follicular fluid ( 1 to $15 \mathrm{mg} /$ female) was diluted in $1.0 \mathrm{ml}$ of phosphate buffer $(\mathrm{pH} 6.9) ; 0.5 \mathrm{ml}$ were used for $\mathrm{P}, \mathrm{E}_{1}$ and $E_{2}$ assays and $0.5 \mathrm{ml}$ for $\mathrm{T}$ and $\Delta_{4}$ assays. We used the techniques described by Castanier and Scholler (1970) for $P, E_{1}$ and $E_{2}$ assays. Androgens were determined according to Roger et al. (1979). Briefly, after the addition of $1000 \mathrm{cpm}$ of radioactive hormones for recovery calculation, unconjugated steroids were extracted with $5 \mathrm{ml}$ of diethyl ether. After the aqueous phase had been deep-frozen, the organic phase was decanted and dried under a stream of nitrogen. $P, E_{1}$ and $E_{2}$ were purified on Sephadex $\mathrm{LH}_{20}$ microcolumns (height: $5 \mathrm{~cm}$; benzene/ethanol, $90 \mathrm{v} / 10 \mathrm{v}$ as eluent) ; $\mathrm{T}$ and $\Delta_{4}$ were purified on celite microcolumns (height : $8 \mathrm{~cm}$; polyethylene glycol as stationary phase, isooctane with increasing proportions of benzene as eluent). 
After chromatography, the eluents were fractioned into three aliquots, one to determine procedural loss ; after the addition of $10 \mathrm{pg}$ of radioactive steroid, the other two aliquots were dried and re-dissolved in $200 \mu \mathrm{l}$ of phosphate buffer containing the diluted antiserum. Bound and free steroids were separated by extracting the free fraction with scintillation fluid, according to Castanier and Scholler (1970).

The mean criteria of assay reliability are shown on table 1. Blank values, run with each assay, were below assay sensitivity. Antisera were kindly supplied by J. Adeline (Fondation de Recherche en Hormonologie, France). The characteristics of $P, E_{1}$ and $E_{2}$ antisera have been described by Marie (1981), those of $\mathrm{T}$ and $\Delta_{4}$ antisera have been reported by Mondain-Monval et al. (1979).

Statistical analysis. - Each female was characterized by 6 variables : sexual behavior score SBS (a non-normally distributed variable) and $P, E_{1}, E_{2}, T$ and $\Delta_{4}$ concentrations in follicular fluid. The last 5 variables were presumed to be normally distributed.

The mean for SBS and the mean \pm standard error of the mean (SEM) were calculated for each steroid concentration. The SBS and steroid concentrations were compared using the method of Kruskal-Wallis and one-way variance analysis, respectively.

To examine the relative differences between the five stages of pseudopregnancy as estimated by the 6 variables taken together, the generalized distance ( $D^{2}$ ) of Mahalanobis was used (Lefebvre, 1980). The significance of calculated $D^{2}$ was tested by the $F$ of Fischer-Snedecor. The distances between the five stages of pseudopregnancy were visualized by projecting their average points and confidence circles to 0.95 on a plane defined by the first two canonical axes. The principal statistical assumption required a common dispersion matrix

TABLE 1

Reliability criteria for steroid radioimmunoassays.

\begin{tabular}{|c|c|c|c|c|c|}
\hline \multirow{2}{*}{$\begin{array}{l}\text { Steroid } \\
\text { assayed }\end{array}$} & \multirow{2}{*}{$\begin{array}{l}\text { Antiserum } \\
\text { used }\end{array}$} & \multirow{2}{*}{$\begin{array}{c}\text { Mean } \\
\text { recovery } \\
\% \\
\text { (range) }\end{array}$} & \multicolumn{2}{|c|}{ Sensitivity (pg) } & \multirow{2}{*}{$\begin{array}{l}\text { Intraassay } \\
\text { coefficient } \\
\text { of variation }\end{array}$} \\
\hline & & & $\begin{array}{l}\text { Standard } \\
\text { curve }\end{array}$ & assay & \\
\hline Progesterone (P) & 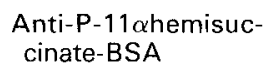 & $\begin{array}{c}92 \\
(70-98)\end{array}$ & 10 & 25 & 11.2 \\
\hline OEstrone $\left(E_{1}\right)$ & $\begin{array}{l}\text { Anti-E } E_{1}-17-0 \text {-car- } \\
\text { boxymethyl-oxime- }\end{array}$ & $\begin{array}{c}95 \\
(70-99)\end{array}$ & 10 & 30 & 8.44 \\
\hline OEstradiol $\left(E_{2}\right)$ & & $\begin{array}{c}94 \\
(67-99)\end{array}$ & 10 & 27 & 7.6 \\
\hline Testosterone (T) & $\begin{array}{l}\text { Anti-T-3-carboxy- } \\
\text { méthyl-oxime-BSA }\end{array}$ & $\begin{array}{c}93 \\
(76-99)\end{array}$ & 5 & 30 & 8.6 \\
\hline Androstenedione $\left(\Delta_{4}\right)$ & $\begin{array}{c}\text { Anti- } \Delta_{4}-3 \text {-carboxy- } \\
\text { methyl-oxime-BSA }\end{array}$ & $\begin{array}{c}92 \\
(82-97)\end{array}$ & 5 & 20 & 8.3 \\
\hline
\end{tabular}


which was graphically controlled. Discriminant functions between stages found to be different from the previous analysis were calculated (Lefebvre, 1980).

To determine concomitant variations between all possible pairs of variables during pseudopregnancy, the correlation coefficients were calculated. The relationship between $E_{1}$ and $E_{2}$ concentrations was studied in three groups of females constituted according to their sexual behavior score : (1) 4 females in deep dioestrus which remained flattened in a corner of the cage during at least 2 tests, (2) 5 oestrous females, (3) the remaining 16 does which did not accept the male but sometimes circled away from him.

The programs of multivariate analysis for a Wang $2200 \mathrm{P}$ computer were developed by Lefebvre, Boitard and Rey (1981).

\section{Results.}

Changes in sexual behavior score and sex steroid concentrations in follicular fluid during pseudopregnancy. - Flattening or circling behavior throughout the test did not vary significantly during pseudopregnancy. Mounting behavior was observed on Days 9 and 18 in one female out of five. One doe showed lordosis on Day 12 and 3 others on Day 18. Thus, the mean behavior score rose at the end of pseudopregnancy (fig. $1 \mathrm{~A}$ ). It seemed that (1) mean oestrogen concentrations were higher on Days 6, 9 and 18 than on Days 12 and $15(39 \pm 9$ vs $23 \pm 4 \mathrm{pg} / \mathrm{mg}$ of follicular fluid for $E_{1} ; 23 \pm 6 \mathrm{vs} 9 \pm 3 \mathrm{pg} / \mathrm{mg}$ of follicular fluid for $E_{2}$ ) (fig. $1 \mathrm{C}$ ) and that (2) $\Delta_{4}$ and $\mathrm{T}$ concentrations were highest on Day $6 ; \mathrm{T}$ levels were minimal on Day 15 (fig. $1 \mathrm{D}$ ). Levels of $E_{1}$ and $T$ were always higher than levels of $E_{2}$ and $\Delta_{4}$.

$P$ concentrations fluctuated between 100 and $200 \mathrm{pg} / \mathrm{mg}$ of follicular fluid, with a minimal value on Day 9 (fig. 1 B).

Nevertheless, classical statistical analysis showed no significant differences during pseudopregnancy either in sexual behavior score or in sex steroid concentrations in follicular fluid, probably due to great individual variations $(P>0.05)$. So, the 5 stages of pseudopregnancy were compared using the generalized distance $\left(D^{2}\right)$ of Mahalanobis, providing a means by which behavioral and endocrine factors could be interrelated simultaneously. Preliminary analysis showed that the contribution of two variables, $E_{1}$ and $P$, to $D^{2}$ was low $(5$ and $3 \%$, respectively, as against at least $14 \%$ for the other 4 variables). The projection of average points and their confidence circle on the plane defined by the first two canonical axes showed that Days 9 and 12 completely overlapped ; Day 15 partially overlapped these two days and Day 6 (fig. 2 A). So, the data from Days 9 and 12 were grouped and the same analysis was performed with 4 variables (SBS, $T, E_{2}$ and $\Delta_{4}$ ). Significant $D^{2}$ values were obtained between Day 6, Days $9+12$ and Day $18(\mathrm{P}<0.025)$ (fig. $2 \mathrm{~B}$ ).

Four periods were then considered during pseudopregnancy: Days 6, $9+12,15$ and 18 . Among the six variables studied, those giving a maximal distance between paired periods were determined by calculating discriminant functions. The sexual behavior score and the two androgens allowed good 


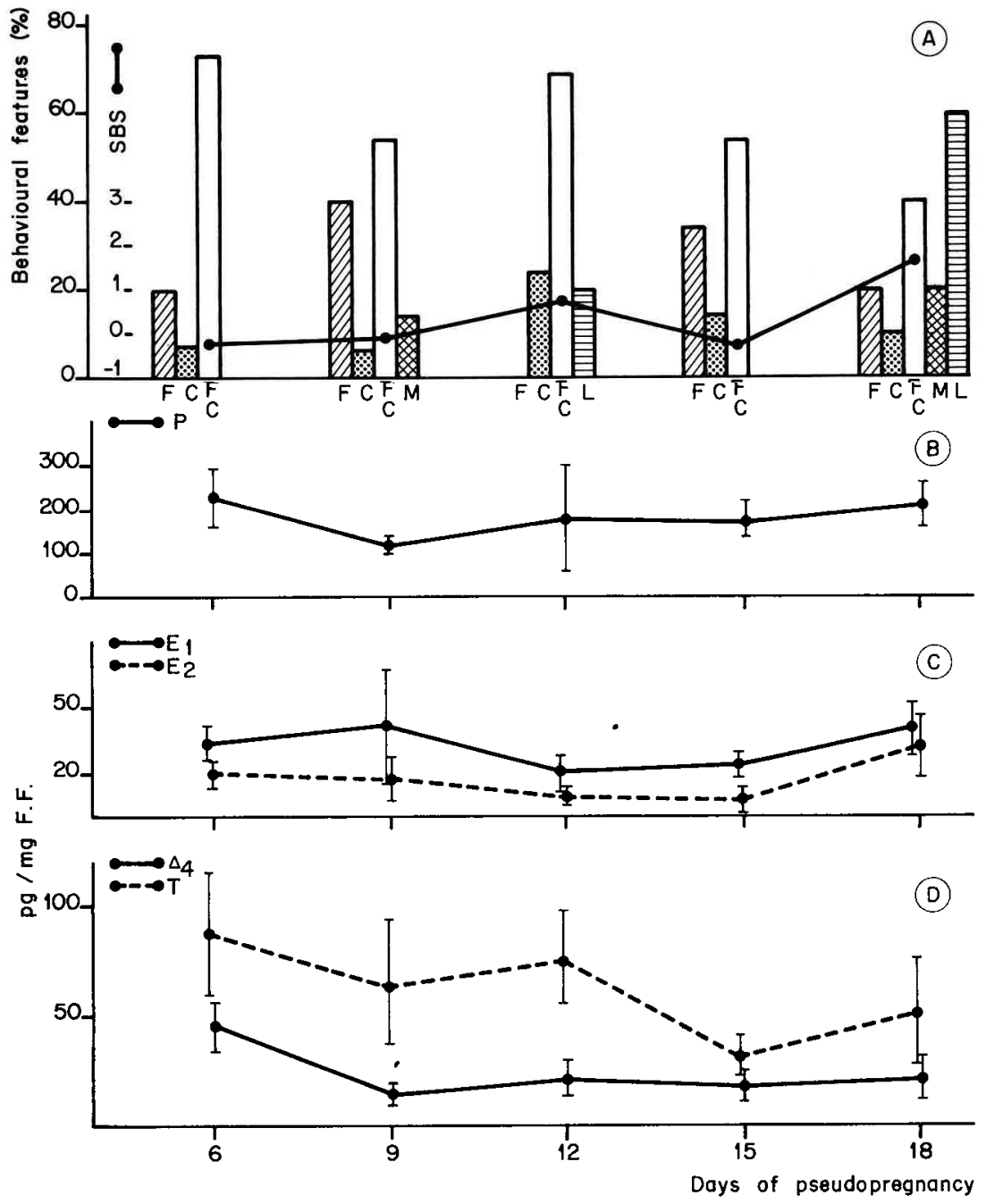

FIG. 1. - (A) : Percentage of tests during which doe rabbits either: $\mathrm{F}:$ flattened in a corner of the cage throughout the test; $\mathrm{C}$ : circled away from the male throughout the test; $\mathrm{FC}$ : alternately flattened and circled during the same test; $\mathrm{M}$ : mounted the male: $\mathrm{L}$ : showed lordosis and accepted mating: (-) changes in mean behavior score (SBS).

Mean \pm sem concentrations of progesterone (B), oestrone ( - ) and oestradiol (- . (C), androstenedione (๑) and testosterone (-.- (D) in follicular fluid during pseudopregnancy.

separation of Day 6 from Days $9+12$ and 18 (fig. 3 A, B). Days $9+12$ and 18 were discriminated by a compound of the main 4 variables (SBS, $E_{2}, T$ and $\Delta_{4}$ ) (fig. $3 \mathrm{C}$ ) and Days 15 and 18 were separated by a compound of 2 variables only: sexual behavior score and progesterone concentrations (fig. 3 D). 

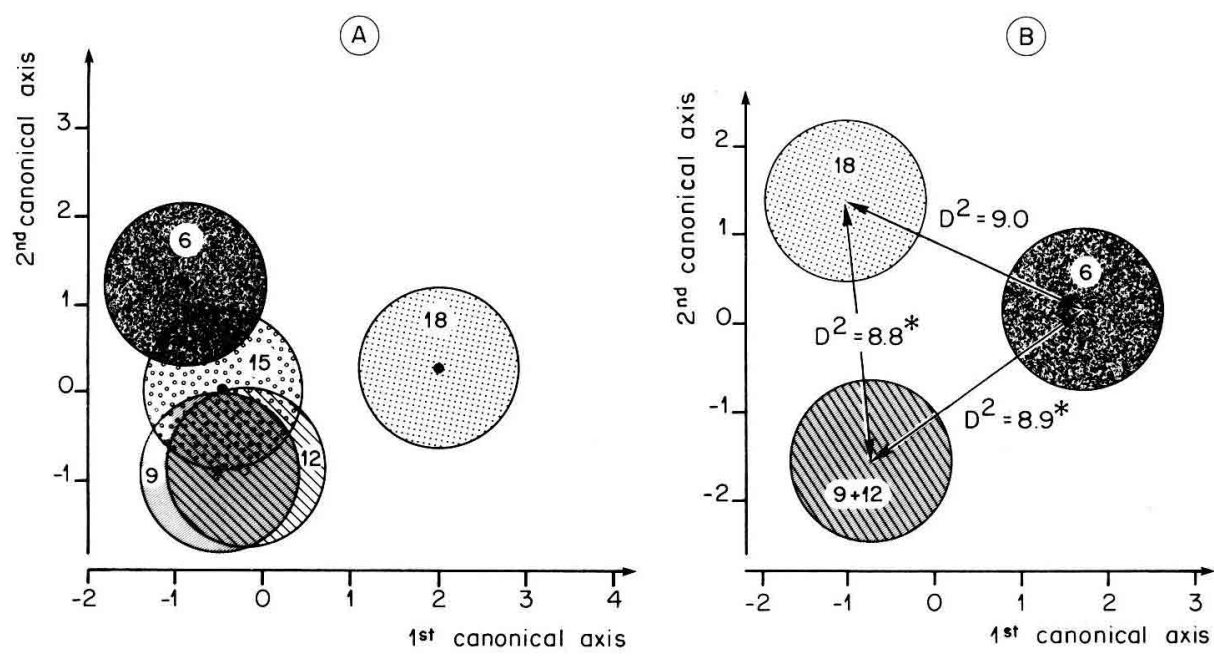

FIG. 2. - Projections of average population points affected by their confidence circles at 0.95 on the plane defined by the first two canonical axes. The differences between the stages of pseudopregnancy depend on the amount of overlap between their confidence circles (Guillaumin and Lefebvre, 1974).

(A): Values of $D^{2}$ between the 5 populations (Days $6,9,12,15$ and 18 of pseudopregnancy) were calculated by using a compound of the sexual behavior score and follicular concentrations of androstenedione testosterone and oestradiol;

(B): The values of $\mathrm{D}^{2}$ between Day 6 , Days $9+12$ and Day 18 were calculated using a compound of the same 4 variables (To simplify the figure Day 15 was omitted).

* Significant $D^{2}$ value $(P<0.025)$.

Relationships between follicular steroid concentrations and sexual behavior during pseudopregnancy. - A significant correlation $(P<0.01)$ was observed between follicular fluid concentrations of $E_{1}$ and $E_{2}(r=0.71), E_{1}$ and $T$ $(r=0.56), E_{2}$ and $T(r=0.49)$ and $T$ and $\Delta_{4}(r=0.78)$. No concomitant variation was found between $P$ concentrations or sexual behavior score and the other variables. However, deeply dioestrous females always had undetectable levels of $E_{2}$ (fig. $4 \mathrm{~A}$ ); follicular concentrations of $E_{1}$ and $E_{2}$ in oestrous and dioestrous females were always detectable and linearly related, whatever the stages of pseudopregnancy (fig. 4 A, B).

\section{Discussion.}

A few rabbits submitted to mating when presented to males on only one definite day during pseudopregnancy. At the end of this period, 3 out of 5 females were receptive. These results confirm the observations of Hammond and Marshall (1925), Friedman (1938) and Rubin and Azrin (1967) who all reported irregular mating during pseudopregnancy and the appearance of oestrous behavior at the end of this period. More females submitted to mating when presented to males every day during pseudopregnancy (Caillol et al., 1983). As already shown by Lefèvre and Moret (1978) in young nulliparous virgin doe 
rabbits, repeated stimulation by the male is effective in inducing oestrous behavior in pseudopregnant rabbits.

There were no clear changes in individual concentrations of follicular sex steroids during pseudopregnancy. However, oestrogen levels seemed lower on Days 12 and 15 than on Days 6 and 18 ; androgen levels seemed minimal on Day 15 , and $P$ levels minimal on Day 9 . The only information on sex steroids in follicular fluid during pseudopregnancy is that of Osteen and Mills (1980) related to follicular size. However, the mean values of $P, E_{2}$ and $T$ found by those authors on Day 6 are similar to our results.

Statistical multivariate analysis shows four periods in pseudopregnancy : Day 6, Days 9 and 12 which are similar, Day 15 which partially overlaps the
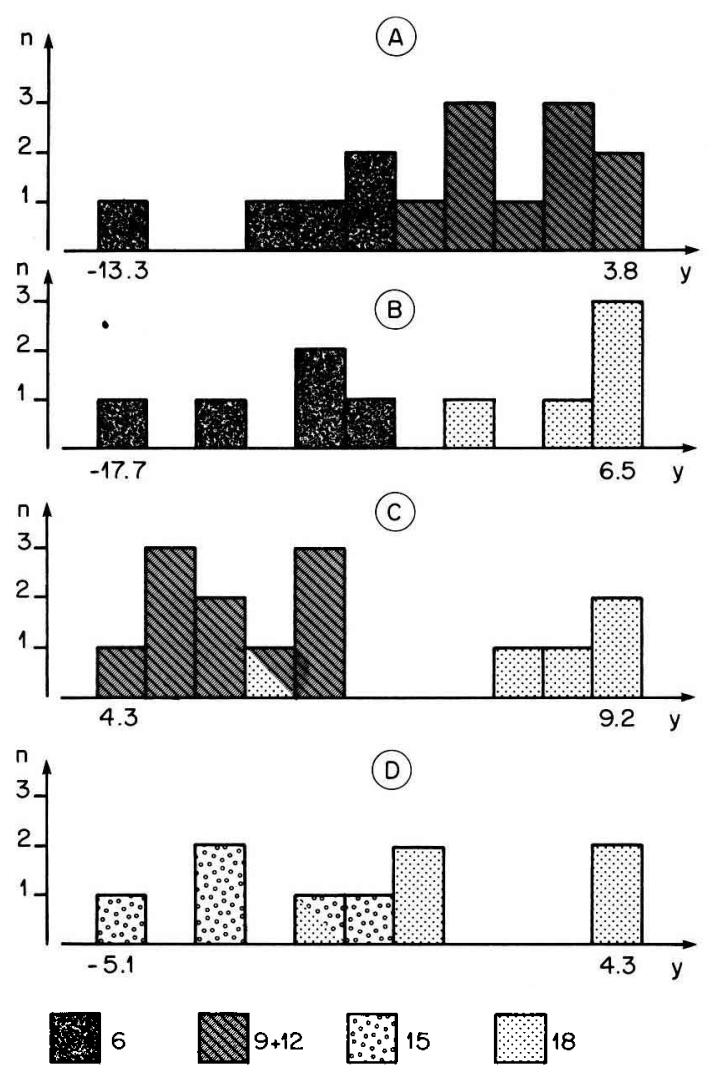

FIG. 3. - Frequency distribution of the discriminating variable $y$ in $=$ number of doe rabbits ; the discriminant variable $y$ for each doe rabbit was obtained by substituting the value of each variable in the discriminant function $Y$ ). For successive paired periods, the discriminant function $Y$ was:
A. $Y=-0.64$ (SBS) $+0.11(T)-0.34\left(\Delta_{4}\right)$ between Days 6 and $9+12$;
B. $Y=4.01$ (SBS) $+0.21(\mathrm{~T})-0.65\left(\Delta_{4}\right)$ between Days 6 and 18 ;
C. $Y=1.98(\mathrm{SBS})-0.12(\mathrm{~T})-0.22\left(\Delta_{4}\right)+0.13 \mathrm{E}_{2}$ between Days $9+12$ and 18 ;
D. $Y=2.40$ (SBS) -1.26 (P) between Days 15 and 18 . 


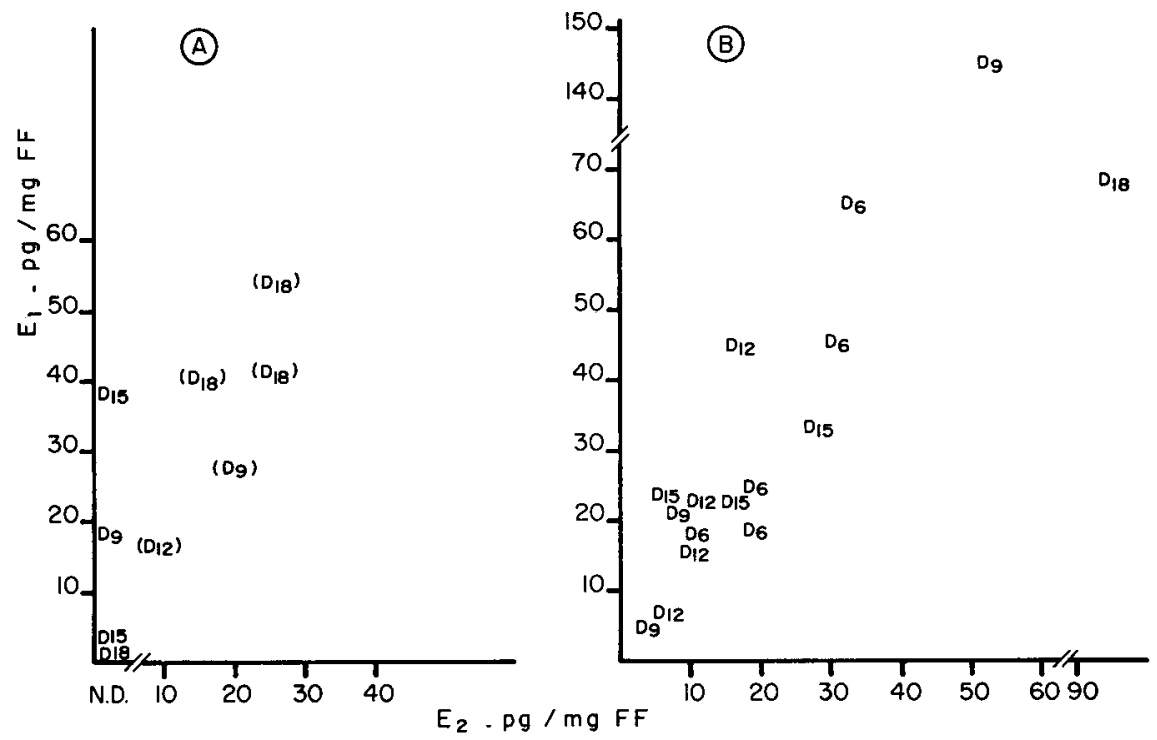

FIG. 4. - Relationships between follicular concentrations of $E_{1}$ and $E_{2}$.

(A) : 4 females in deep dioestrus $D_{n}$ and 5 oestrous females $\left(D_{n}\right)$;

(B) : 16 dioestrous females $D_{n}$ sometimes circling away from the male.

Each female is represented with the stage of pseudopregnancy, $D_{n}$.

preceding two periods, and Day 18. Sexual behavior score, androgen and oestradiol concentrations in follicular fluid are effective in discriminating between these stages. These four periods have been characterized by other endocrinological or comportmental events.

Day 6 is a key period in pseudopregnancy. The corpus luteum becomes an oestradiol-dependent tissue (Miller and Keyes, 1978) and luteotropic oestrogen is supplied by the large follicles on the ovary (Keyes and Nalbandov, 1967). From Day 6, the proportion of oestrous females significantly decreases (Caillol et al., 1983).

Days 9 and 12 correspond to the period of maximal circulating levels of progesterone (Harrington and Rothermel, 1977 ; Richardson and Oliphant, 1981 ; Caillol et al., 1983). Few females are receptive (Caillol et al., 1983). The discriminant function shows that this period differs significantly from Day 6 as to sexual behavior and androgen concentration in follicular fluid.

Day 15 corresponds to the period of luteolysis (Carlson and Gole, 1978 ; Satoh et al., 1980). Our results show that oestrogen and androgen concentrations in follicular fluid are depressed and that the sexual behavior score is minimal.

Day 18 corresponds to the end of pseudopregnancy and clearly differs irom all the other stages. Circulating $P$ levels are very low (Caillol et al., 1983). In our study, most females were receptive, concentrations of sex steroids in follicular fluid rose, and the most efficient variables discriminating this stage from Day 15 were sexual behavior and $\mathrm{P}$ concentrations in follicular fluid. 
Correlation analysis showed some metabolic pathways of steroidogenesis in follicles; $E_{1}$ and $E_{2}$ concentrations, as well as those of $T$ and $\Delta_{4}$, were significantly correlated due to the possibility of interconversion between these steroids (Younglai, 1972, 1973). T concentrations were also correlated to $E_{1}$ and $E_{2}$ concentrations, and $T$ is known to be the immediate precursor of $E_{2}-17 \beta$ synthesis in the follicle (Younglai, 1972 ; Patwardhan and Lanthier, 1977 ; Marchut, 1977).

During pseudopregnancy, there was no clear relationship between sexual behavior score and the concentrations of progesterone, oestrone and androgens in follicular fluid. Deeply dioestrous doe rabbits were found to have undetectable levels of oestradiol in the follicular fluid, whereas oestrous or dioestrous ones always had detectable levels of oestradiol linearly related to those of oestrone. In non-pregnant non-pseudopregnant females, Lefèvre and Caillol (1978) have shown that the follicular fluid of oestrous rabbits contains more oestrone, oestradiol and progesterone than the fluid of dioestrous rabbits. The high circulating progesterone levels during pseudopregnancy probably complicate the relationship between sexual behavior and follicular sex steroids. Nevertheless, the presence of oestradiol in follicular fluid seems to be necessary to ensure minimal sexual activity. This finding partially confirms other results showing that oestradiol injections in ovariectomized rabbits promote oestrous behavior (Beyer and McDonald, 1973) and that active immunization against oestradiol-17 $\beta$ inhibits this behavior (Elsaesser, 1980).

Reçu en décembre 1982 ,

Accepté en novembre 1983.

Acknowledgements. - The authors wish to thank the "Fondation de Recherche en Hormonologie " for help and advice concerning the radioimmunoassays and L. Martinet for her helpful criticisms of the paper.

Résumé. Stéröides sexuels folliculaires et comportement pendant la pseudogestation chez la lapine.

Les variations du comportement sexuel et des concentrations en progestérone, œstrone, œestradiol, testostérone et androsténedione dans le liquide folliculaire ont été recherchées chez 25 lapines aux $6^{\mathrm{e}}, 9^{\mathrm{e}}, 12^{\mathrm{e}}, 15^{\mathrm{e}}$ et $18^{\mathrm{e}}$ jours de pseudogestation. II semble que le score de comportement sexuel augmente à la fin de la pseudogestation et que les niveaux de stéroïdes folliculaires soient plus élevés aux $6^{e}$ et $18^{\mathrm{e}}$ jours de la pseudogestation qu'aux $9^{\mathrm{e}}, 12^{\circ}$ et $15^{\mathrm{e}}$ jours. Le calcul de la distance généralisée $\mathrm{D}^{2}$ de Mahalanobis a montré l'existence, au cours de la pseudogestation, de 4 périodes distinctes : le $6^{\mathrm{e}}$ jour, les $9^{\mathrm{e}}$ et $12^{\mathrm{e}}$ jours qui sont similaires, le $15^{\mathrm{e}}$ et le $18^{\mathrm{e}}$ jour. Les 4 périodes diffèrent par une combinaison de 4 variables (score de comportement sexuel, concentrations en androgènes et oestradiol du liquide folliculaire). II n'y a pas de relation entre le comportement sexuel et les niveaux de stéroïdes folliculaires ; cependant, les niveaux d'œestradiol sont non détectables dans le liquide folliculaire uniquement pour les lapines en diøestrus profond. 


\section{References}

BEYER C., McDONALD P., 1973. Hormonal control of sexual behaviour in the female rabbit. Adv. reprod. Physiol., 6, 185-214.

CAILLOL M., DAUPHIN-VILLEMANT C., MARTINET L., 1983. OEstrous behaviour and circulating progesterone and oestrogens levels during pseudopregnancy in the domestic rabbit. $J$. Reprod. Fert., 69, 179-186.

CARLSON J. C., GOLE J. W. D., 1978. CL regression in the pseudopregnant rabbit and the effects of treatment with prostaglandin- $\mathrm{F}_{2} \alpha$ and arachidonic acid. J. Reprod. Fert., 53, 381 . 387.

CASTANIER M., SCHOLLER R., 1970. Dosage radioimmunologique de l'oestrone et de l'oestradiol $17 \beta$ plasmatiques. C. R. Acad. Sci. Paris, Sér. D, 271, 1787-1789.

ELSAESSER F., 1980. Effects of active immunization against oestradiol-17 $\beta$, testosterone or progesterone on receptivity in the female rabbit and evaluation of specificity. J. Reprod. Fert., 58, 213-218.

FRIEDMAN M., 1938. Criteria for the selection of estrous rabbits. Endocrinology, 22, 354-359.

GUILLAUMIN M., LEFEBVRE J., 1974. Etude biométrique des populations de Pyrgus Carlinae Rbr et de Pyrgus Cirsii Rbr. II. Utilisation du $D^{2}$ de Mahalanobis dans I'analyse et la classification des populations naturelles. Arch. Zool. Exp. Gen., 115, 505-548.

HAMMOND J., MARSHALL F., 1925. Reproduction in the rabbit. Oliver and Boyds, Edinburgh.

HARRINGTON F. E., ROTHERMEL J. D., 1977. Daily changes in peripheral plasma progesterone concentrations in pregnant and pseudopregnant rabbits. Life Sci., 20, 1333-1340.

KEYES P. L., NALBANDOV A. V., 1967. Maintenance and function of corpora lutea in rabbits depend on estrogen. Endocrinology, 80, 938-946.

LEFEBVRE J., 1980. Introduction aux analyses statistiques multidimensionnelles. Masson, Paris. $251 \mathrm{pp} .2^{\mathrm{e}}$ édition révisée et augmentée).

LEFEBVRE J., BOITARD M., REY J. E., 1981. Logiciels d'analyses statistiques multidimensionnelles sur microordinateurs. Masson, Paris, $148 \mathrm{pp}$.

LEFEVRE B., CAILLOL M., 1978. Relationship of estrous behaviour with follicular growth and sex steroid concentration in the follicular fluid in the domestic rabbit. Ann. Biol. anim. Bioch. Biophys., 18, 1435-1441.

LEFĖVRE B., MORET B., 1978. Influence d'une modification brutale de l'environnement sur l'apparition de l'œestrus chez la lapine nullipare. Ann. Biol. anim. Bioch. Biophys., 18, 695698.

MARCHUT M., 1977. In vitro conversion of $\left[4-{ }^{14} \mathrm{C}\right]$ Androstenedione and $\left[4-{ }^{14} \mathrm{C}\right]$-testosterone by ovarian tissue of pregnant rabbits. Endocrin. Exper., 11, 195-202.

MARIE J., 1981. Concentrations tissulaires et plasmatiques d'hormones stéroïdes et récepteurs utérins de l'cestradiol chez la ratte preparturiente: étude d'un modèle expérimental présentant des anomalies de la parturition. Th. Doct. $3^{e}$ cycle. Univ. Paris VI, 36 pp.

MILLER J. B., KEYES P. L., 1978. Transition of the rabbit corpus luteum to oestrogen dependence during early luteal development. Endocrinology, 102, 31-38.

MONDAIN-MONVAL M., BONNIN M., SCHOLLER R., CANIVENC R., 1979. Androgens in peripheral blood of the red fox (Vulpes Vulpes L.) during the reproductive season and the anoestrus. J. Steroid Biochem., 11, 1315-1322.

OSTEEN K. G., MILLS T. M., 1980. Changes in the size, distribution and steroid content of rabbit ovarian follicles during early pseudo-pregnancy. Biol. Reprod., 22, 1040-1046.

PATWARDHAN V. V., LANTHIER A., 1977. Pathways for the biosynthesis of oestradiol in the rabbit ovarian follicle in vitro. J. Endocrinol., 75, 445-446.

RICHARDSON L. L., OLIPHANT G., 1981. Steroid concentrations in rabbit oviducal fluid during oestrus and pseudopregnancy. J. Reprod. Fert., 62, 427-431.

ROGER M., NAHOUL F., TOUBLANC J. E., CASTANIER M., CANLORBE P., JOB J. C., 1979. Les androgènes plasmatiques chez le garçon de la naissance à l'adolescence. Ann. Pediat., 26, 239-245.

RUBIN H. B., AZRIN N. H., 1967. Temporal patterns of sexual behavior in rabbits as determined by an automatic recording system. J. exp. anal. Behav., 10, 219-231. 
SATOH K., KAWAI Y., MITSUHASHI N., KINOSHITA K., SAKAMOTO S., 1980. Prostaglandin $\mathrm{F}_{2}$ alpha metabolites in plasma and urine during pseudopregnancy in the rabbit. Am. J. Obst. Gynecol., 138, 748-754.

YOUNGLAI E. V., 1972. Effect of mating on follicular fluid steroids in the rabbit. J. Reprod. Fert., 30, 157-159.

YOUNGLAI E. V., 1973. The bioconversion of androstenedione and testosterone by rabbit granulosa cells and the effects of ovine LH on thecal aromatization. Steroids Lipids Res., 4, 11-16.

YOUNGLAI E. V., 1981. Effects of in vivo administration of sex hormones on luteinizing hormone-stimulated steroid accumulation by isolated rabbit ovarian follicles. J. Endocrinol., 91, 495-500. 